\title{
Imagine the EU: the metaphorical construction of a supra-nationalist identity
}

\author{
Rainer Hülsse \\ Geschwister-Scholl-Institut, Ludwig-Maximilians-Universität München, Oettingenstr. 67, D-80538 \\ München, Germany. \\ E-mail: rainer.huelsse@1rz.uni-muenchen.de
}

The European Union (EU) is a novel political entity in many respects. For example, instead of the monolithic political structure of nation-states, it features a layered structure and a 'variable geometry'. This institutional complexity has been interpreted as an indicator of the EU being a post-modern political system. This article inquires whether the EU's institutional post-modernness is accompanied by a post-modern identity. I argue that an investigation of collective identity requires a reconstruction of how a community is imagined. As metaphors are the principal linguistic means of our imagination, I reconstruct the imaginations of the European community by analyzing its metaphorizations. How do the metaphors of EU enlargement construct European identity? It can be shown that in the German EUenlargement discourse of the 1990s, European identity was hardly constructed in a post-national/post-modern way. Rather, European identity was imagined much like a modern national identity.

Journal of International Relations and Development (2006) 9, 396-421. doi:10.1057/palgrave.jird.1800105

Keywords: discourse; European identity; EU enlargement; metaphor

Imagine there's no countries, it isn't hard to do. Nothing to kill or die for and no religion, too. Imagine all the people living life in peace. You may say I'm a dreamer, but I'm not the only one. I hope some day you'll join us and the world will be as one (John Lennon, 'Imagine', 1972).

\section{Introduction}

John Lennon is not known for his expertise in European integration. It is safe to assume then that it was not the European Community he had in mind when 35 years ago he called upon his listeners to imagine a post-national world. But perhaps, it is the European Union (EU) that is making his dream come true. John Ruggie is not a great musician (as far as I know, at least), but certainly an expert on international politics. And he has described the EU as the first postmodern polity (Ruggie 1993). As such, the EU may be a model for overcoming 
the modern age, characterized by and often suffering from nations and their nationalisms. Of course, it is unlikely that in a post-national/post-modern world there would be 'nothing to kill or die for', as suggested by John Lennon. But, as nationalism is certainly one of the prime sources of violence in the human condition, the hope is for a post-national world that is more peaceful than the modern world of nation-states. However, is it at all justified to describe the EU as a post-national political system, as a model for escaping modernity? Is the EU actually developing a post-national identity and thus taking us beyond the Westphalian system? Or is it merely replicating the national identities of the European nation-states on a higher, European level (Manners and Whitman 2003)? Students of International Relations (IR) are divided over these questions: some tend towards the former view and emphasize the postmodern/post-national character of the EU and European identity. ${ }^{1}$ Other scholars are closer to the latter view and point out how European identity is shaped by the exclusion and othering of 'them', most notably of Turkey. This, they argue, is reminiscent of national/modern identities, the reason why European identity is best described as supranationalist. ${ }^{2}$

This article takes up this issue, though looking at it from a different perspective. In the literature evidence for either position, but especially for the post-national one, is taken mostly from the 'real world' - political structures and actions. However, if we take the idea that communities are imagined (Anderson 1983) seriously, it is hardly convincing to only look at what the EU does in order to make a judgement about its identity. Instead, one needs to take account of how the EU or Europe is imagined in discourse. ${ }^{3}$ As imaginizations are nowhere more apparent than in the linguistic means of imagining, such as metaphors, this article approaches the issue of European identity by looking at its metaphorizations. Metaphors are a means of imagining and by the same token constructing social reality. This has to do with their very logic of operation: they project the meanings of a familiar issue onto a less familiar and abstract one, thus constituting the unknown in terms of the known.

To decide whether European identity is constructed according to the national model or in a post-national way, I will analyze the 1990s' discourse on EU Eastern enlargement. This discourse is particularly interesting for students of identity since it deals with self/other relations. The EU's former others, the Central and Eastern European countries (CEECs), wanted to become part of the self. This put old understandings of Europe into question and forced the EU to reflect upon itself and its future borders (Anderson 1998; Fierke and Wiener 1999: 273; van Ham 2001: 189; Kuus 2005; Murphy 2005). The enlargement-discourse can thus be read as an identity-discourse. For the reasons specified below, the article concentrates on the metaphors in one particular EU member's discourse on EU enlargement, Germany. Perhaps, things would have looked differently in other member states, but my 
observations for the German case must disappoint those hoping for a postnational European identity. The enlargement-metaphors employed in the German discourse construct a European identity very similar to national identities.

The remainder of this article is structured as follows: first, I will develop a model of collective identity that allows for differentiating between national and post-national identities as this is the precondition for answering the principal research question. Then, I will discuss the role of metaphors in discourse and how they can be analyzed. Next comes the empirical analysis of the enlargement-metaphors and their constructions of European identity. The final section summarizes the main findings and draws some tentative conclusions.

\section{Identity}

During the 1990s, many IR scholars took the constructivist turn and - while turning - discovered that questions of collective identity are important to the understanding of international politics. ${ }^{4}$ Ontologically, there was broad agreement in at least three respects. First, that collective identities are social constructions and not essential characteristics of collectivities. ${ }^{5}$ Second, that there can be no identity without difference. ${ }^{6}$ Third, that there are basically two ideal types of collective identity, here called primordial and civic. ${ }^{7}$ These ontological assumptions are also shared in most studies of European identity, one of identity scholars' favourite empirical research-objects. Consequently, much of the literature on European identity is constructivist (Hedetoft 1997: 148). ${ }^{8}$ A number of studies examines the construction of the European self in relation to its others. ${ }^{9}$ And the distinction between two types of identity is often applied, though there is a disagreement about whether European identity is more akin to the primordial or the civic type. ${ }^{10}$

The present article also shares this ontology: it is constructivist in that it claims that metaphors of EU enlargement construct a European identity; it takes the self/other-nexus seriously as it reads the discourse on EU enlargement as an identity-discourse, and it builds upon the primordial vs civic distinction. However, I will show that the primordial-civic distinction must not be mistaken for a distinction between national/modern and post-national/postmodern identity. ${ }^{11}$ There exist both primordial national identities and civic national identities. Hence, this distinction alone does not allow us to answer the question of whether European identity is just a remake of modern/national identity or a prototype of post-modern/post-national identity. Therefore, I will introduce a second distinction - between a digital and an analog mode of 
differentiation - and combine the distinctions within a two-dimensional model of identity.

The first dimension of the model takes up the distinction between the primordial and civic, specifying that it denotes different sources of identity/ difference. Collective identities constructed according to the primordial type are based (more exactly: are imagined to be based) on some inherent characteristics of the collectivity, for example, a common culture, language or ethnicity. It is a 'thick' identity, taken to be naturally given (Torfing 1999: 195). Ferdinand Tönnies has described such collectivities as Gemeinschaft (community), which 'relates to a certain sense of belonging based on shared loyalties, norms, and values, kinship or ethnic ties; it is conditioned by the feeling that this is a 'natural' and organic association based on an a priori social unity' (van Ham 2001: 59, emphasis in the original). Germany is often cited as the prime example for a national identity based on primordial sources (Wæver 2002: 3-35; Bruter 2003: 1155). However, one should note that while this correctly describes the traditional German approach to identity, a number of civic elements have been introduced to the German identity since World War II. Consequently, the German identity today is arguably more of a primordialcivic mix than still being the prototype of primordial identity it used to be. ${ }^{12}$

Collective identity constructed according to the civic type, in contrast, is not imagined to be a natural given but it results from social interaction within a political entity. Rather than identifying with a nation (defined through a common culture), people identify with a state (Bruter 2005: 12). It is an acquired political identity rather than an inherited cultural identity (Rumelili 2004: 37). This 'thin' type of identity is reminiscent of Tönnies' concept of Gesellschaft (society) (Torfing 1999: 195; van Ham 2001: 59; also Schimmelfennig 2001: 166) and France is considered its prime example (Calhoun 2001: 41; Wæver 2002: 34-35; Bruter 2003: 1155). In a nutshell, the primordial vs civic distinction is about cultural vs political sources of identification and, by the same token, differentiation.

The second dimension of my identity-model focuses on the 'mode of differentiation' (Ruggie 1993: 168, emphasis added) between the self and other. I take up Iver Neumann's (1998) distinction between a 'digital' and an 'analog' mode, each describing a particular way of organizing the boundary between the self and other (also Wæver 2004: 210). The digital mode of differentiation constructs the other in total contrast to the self, establishing a binary opposition between the two. The border is clearcut, there is only the self and other, with nothing in-between. Obviously, the digital mode of differentiation produces very exclusive identities. Further, there is hardly a lack of examples for this mode: not only national identities of the primordial type but also those of the civic type draw a clear, unambiguous line between the self and other. In fact, I would hold that any state organizes its boundary according to the digital 
mode. That the world is divided up into states, each of which has its clearly defined territory and hence a clearcut border, is precisely the characteristic of the Westphalian system (Ruggie 1993). The digital mode is without doubt the modern mode of differentiation.

However, one can conceive of boundaries not only as a clearcut border, as a line, but also as a frontier, as a more ambiguous 'in-between space' (Bhaba 1996). This is the case of the analog mode of differentiation, where difference is produced in a nuanced and gradual rather than in a sharp and absolute way (Wæver 2004: 210). Here, differentiation is understood to be more like a continuum than a binary opposition. From this perspective, the other is different in degree rather than in kind (Manners and Whitman 2003: 386). Between the two, there are 'large zones of transition' (Ruggie 1993: 150), where the self and other overlap in multiple ways. This frontier zone is populated by hybrids, which cannot be said to be either inside or outside (Rumelili 2004: 289). Such a mode of differentiation produces much more inclusive identities.

As the digital mode of differentiation characterizes modernity, looking for current empirical evidence for the operation of the analog mode amounts to searching for a post-modern collectivity. Obviously, this is not an easy task. Modern states have to rely on the digital mode of differentiation, as it is constitutive for their existence. Should a state abolish its border (not to be mistaken for border control) and conceptualize it as an in-between space instead, it would cease to be. However, according to some scholars, the EU is a post-modern collectivity. Should this be so, we should be able to demonstrate that its mode of differentiation is analog, not digital.

At first glance, however, it appears as if the EU also employs the digital mode as it has clearly defined external borders. However, in contrast to state borders, the borders of the EU have frequently been subject to change. Many of the countries, which today are member states, used to be on the other side of the EU border only a few years ago. Hence, one could argue that, despite the EU having a clearcut border between the inside and outside at any given moment, the possibility that this border will be moved in the future undermines its rigidness. This cuts an opening into the digital mode of differentiation (cf. Derrida 1992: 17). More importantly, the EU has not just a single border but a plurality of borders, each for a different purpose. For example, as far as currency is concerned, the Euroland border runs right through the member states; with regard to the control of national borders, the Schengenland border is peculiar in that it excludes some EU members (United Kingdom, Ireland), while it includes some countries that are not even members of the EU (Iceland, Norway and, from 2007, Switzerland). And many other distinctions are operative as well. For example, there are those candidate countries that are not yet EU members, but will become so in 2007 (Bulgaria, Romania). There are also the official candidates without a fixed date for accession (Turkey, 
Croatia, Macedonia), countries that are part of the customs union (Turkey, San Marino, Andorra), the European Free Trade Area (EFTA) countries that can trade freely with the EU (Norway, Iceland, Liechtenstein) and the many countries that are targeted by the EU's European Neighbourhood Policy (e.g. Algeria, Israel, Moldova, Ukraine) - a list that could easily be extended.

A variety of metaphors is in use to capture this feature of the EU's multiple borders, including 'patchwork Europe' (Agnew 2001: 30), 'layered frontier zones' (Buzan and Diez 1999: 49), 'variable geometry' (Wæver 2004: 210) and 'concentric circles' (Buzan and Diez 1999: 52; Moravcsik 2001: 121). ${ }^{13}$ The important point for us is that while all the 'concentric circles' just described make a clear distinction between those inside and those outside the respective circle, when taken together they make it extremely difficult to distinguish between the self and other. The clearcut line becomes fuzzy, turning it into an ambiguous frontier zone (Christiansen et al. 2000: 392; Walters 2004: 676). A country can be outside for some purposes and yet inside for others (Buzan and Diez 1999: 49, 53; Manners and Whitman 2003: 386). This adds up to a geography where 'Europe fades out' (Wæver 1996: 122, footnote 14). This fading out has the additional effect of making the more aggressive forms of othering increasingly difficult. As the other in one context may in a different context be part of the self, it cannot be denounced as an absolute other or as a constant threat. All this seems to suggest that, indeed, the EU makes use of the analog mode of differentiation.

The result of distinguishing between sources and modes of identification/ differentiation is a two-dimensional model of identity, which can be presented in the form of a $2 \times 2$ table (Table 1 ). ${ }^{14}$

The examples mentioned above can now be fitted into this table. German identity has traditionally been based on primordial sources, its mode of differentiation being digital. French identity is civic and digital. As to the EU, I have demonstrated that its political structure indicates an analog mode of differentiation. I have not discussed the source of European identity, but for the time being let us assume those authors who see it founded on civic sources are right (e.g. Wæver 1998; Schimmelfennig 2001; Manners and Whitman 2003).

Table 1 The two-dimensional model of identity

Mode of differentiation

\begin{tabular}{llll} 
& & Digital & Analog \\
\cline { 3 - 4 } Source of differentiation & Primordial & Germany (traditionally) & Unlikely \\
& Civic & France & EU \\
\hline
\end{tabular}


This means that the EU occupies the lower-right area of our table. ${ }^{15}$ As to the field on the upper-right-hand side, the combination of primordial source and analog mode, I cannot provide an empirical example. In fact, I would hold this to be an unlikely couple. If the difference between the self and other is natural, it should also be fairly clearcut. Hence, one would expect an analog mode to go hand in hand with civic source - the one combination that I would call postmodern/post-national.

The EU has been placed above in the field on the bottom right, which marks its identity as post-modern. This assessment, however, has been based on conventional empirical evidence about what the EU is doing. However, I argued in the introduction to this article that identities are imagined as much as they are done. And it is the imaginization and construction of identity through metaphors that is of interest here. Consequently, I will now apply the two-dimensional model of identity to imaginizations of Europe. How is the EU/Europe imagined in discourse? Does the above categorization of European identity as civic plus analog hold? Or do the metaphors construct a European identity more like the French or even German identity and hence as a modern identity on a larger scale, that is, as a supra-nationalist identity? Before turning to these questions, let me describe my understanding of metaphors and the role they play in the construction of identity.

\section{Metaphor}

The very same constructivist turn that put identity on the IR agenda during the 1990s also led to a shift of attention from what was until then understood to be directly observable empirical reality to representations. A growing number of scholars became interested in discourse and language, basically arguing that social reality is a discursive construction (Torfing 2005). In this view, "things" do not have meaning in and of themselves, they only become meaningful in discourse' (Wæver 2004: 198). As debate about how discourse makes things mean took off, some authors acknowledged the importance of metaphors (Campbell 1998: 7; Milliken 1999: 235). Although metaphor analysis remains quite marginal in IR, there are now a number of empirical metaphor analyses, especially in the subfield of European integration. ${ }^{16}$ Interestingly, many of these studies are not very poststructuralist at all but are instead built on cognitive linguistics and the seminal work of Lakoff and Johnson (1980). This may be due to the fact that much of the debate on metaphors of international politics, especially of metaphors of European integration, emanates from language rather than from IR departments. $^{17}$ 
What is a metaphor and how does it work? According to classical rhetoric, a metaphor is nothing but a substitute for the proper term. It serves as an embellishment for one's speech (Chilton 1996: 359; Charteris-Black 2004: 25). While relatively outdated, this view well describes the IR mainstream's understanding of metaphors to this very day. Metaphors are found to be mere rhetoric and as such irrelevant for political analysis. But metaphors are more than ornamental substitutes for original words. By mapping a source domain (i.e. the new term) onto a target domain (i.e. the original term), a metaphor puts the target domain into a new light (Schäffner 1996: 32; Charteris-Black 2004: 13). Or, to put it in more constructivist terms: through the projection from the known to the unknown, metaphors create reality. They constitute the object they signify.

Owing to their very logic of operation, metaphors should make for a 'natural' research-object of constructivists. They should also enjoy the attention of social constructivists, as metaphors are very much social phenomena. While there certainly is the rare creative moment when we invent a new metaphor, most of the time we speak in metaphors many others have used before us. Often we are not even aware of our metaphors. We use them automatically, as this is the established way of relating to certain topics (Charteris-Black 2004: 17). Linguists in this respect distinguish three types of metaphors, varying in the degree their use is habitualized. Creative metaphors are the least, dead metaphors the most habitualized, with conventional metaphors situated inbetween (Böke 1997: 167; Charteris-Black 2004: 17-19). That we mostly use metaphors many others have used before us - that is, conventional and dead metaphors - explains why metaphorical variation in most discourses is surprizingly low. As to the discourse on Europe, for example, "there are a few metaphors which seem to dominate political thinking about European integration' (Schäffner 1996: 36). In part, the high habitualization of metaphor use might account for the fact that political discourses in general are quite coherent (Wæver 2004: 199-200).

How can the limited variation of metaphors in discourse be explained? Language may be understood as the result of people successfully making sense of the world by framing the new in terms of the old. Frames that have proven to be helpful are sedimented into the body of collective knowledge, the most important repository of which is language. Through a process of 'objectivation' (Berger and Luckmann 1966), metaphors get firmly linked to the objects they signify. We all — at least when talking the same language — use very similar metaphors when speaking about a specific topic because our language provides us with interpretations, which are part of our collective knowledge. Every discourse has a particular stock of metaphors that is commonly used when referring to the discourse topic. If we participate in that discourse we have to 
use the metaphors associated with it (cf. Doty 1993). Hence, we quite automatically use the conventional metaphors the discourse supplies us with. Against this background, conventional metaphors are to be understood as discursive phenomena that are largely beyond individual control (cf. Milliken 1999: 235, footnote 15).

Looking at metaphors from a discourse analytical perspective, my interest is with metaphors' reality-constituting role. What I am not interested in, by contrast, are the cognitive processes behind metaphor use. This is the terrain of cognitive linguistics, which basically argues that metaphorical language use is a reflection of the way we think (Lakoff and Johnson 1980: 6; Fairclough 1992: 194; Chilton and Ilyin 1993: 9; Chilton and Lakoff 1995: 38; Chilton 1996: 43, 48; Schäffner 1996: 31; Charteris-Black 2004: 9, 22). The analysis of metaphorical language, in this perspective, gives access to the (hidden) structures of our thinking, to people's attitudes (Musolff 2000: 4), to 'the covert (and possibly unconscious) intentions of language users' (Charteris-Black 2004: 34) or - in the case of critical discourse analysis - to 'ideological motivations' (Charteris-Black 2004: 29). Metaphor analysis, from this perspective, enables us 'to look behind the explicit utterance and find out conceptual structures that speakers are not aware of' (Musolff 2000: 23). This stands in contrast to discourse analysis, which 'does not try to get to the thoughts or motives of the actors, their hidden intentions or secret plans' (Wæver 2005: 35). Instead, discourse analysis remains at the level of discourse, trying to reconstruct how it shapes social reality (Tonkiss 1998: 248-249). Accordingly, my discourse analytical approach to metaphors is not interested in the thinking behind metaphors, but in the reality that follows from metaphor use, hence with the effects of metaphors on social reality. Metaphors, in this view, shape reality and in consequence condition the possibilities for political action (cf. Wæver 2005: 35).

Having stated the goal of my analysis - reconstructing metaphors' construction of reality - let me briefly explain how I go about this task. Basically, I take up Umberto Eco's (1995: 191) suggestion to interpret metaphors from the point of view of someone who encounters the metaphor for the first time. ${ }^{18}$ The idea is to pretend ignorance about the target domain, in my case: EU enlargement. The only way to find out what EU enlargement is about is to look at its metaphorizations. Hence, I 'manually' reconstruct the projection from the source domain (about which I have knowledge) to the target domain (of which I am ignorant), which has become automatized in the use of conventional metaphors. With this technique of spelling out what appears to be obvious, that is, the de-automatization of the usually automatic projection from source to target, one can reconstruct the reality constructions of metaphors. ${ }^{19}$ 


\section{Metaphors, Enlargement and Identity}

Enlargement to the East was one of the major political issues in the EU during the 1990s. Shortly after the Cold War ended, the former communist countries of Central and Eastern Europe declared that they wanted to become members of the EU as soon as possible. The EU responded by concluding association agreements with the first set of countries in 1991 and by declaring 2 years later that all associated CEECs would in principle be eligible for membership. In 1997, the European Council decided to start accession negotiations with a first group of CEECs (Hungary, Poland, Czech Republic, Estonia, Slovenia) plus Cyprus and appointed all other CEECs official accession-candidates, a status it denied to the long-time applicant Turkey. In 1999, the EU decided to commence actual negotiations with the second group of CEECs (Bulgaria, Romania, Latvia, Lithuania, Slovakia) plus Malta. All but two of the CEECs joined the EU in May 2004 with the remaining two, Bulgaria and Romania, to follow in $2007 .^{20}$

These political decisions did not come out of the blue but were part of a discourse on EU enlargement. This discourse produces both political decisions about enlargement and a certain understanding of the EU. It deals with the future shape of the EU, its boundaries, criteria for membership and its relationship to its former and future others. All these are questions of identity. Apparently, the enlargement-discourse constructs European identity and may thus be read as an identity-discourse. This chapter analyzes the metaphors found in the enlargement-discourse and how they construct both enlargement and European identity. The analysis concentrates on the German discourse, more precisely on parliamentary debates about EU enlargement to the East in the German Bundestag between 1990 and 2000. ${ }^{21}$ Germany is widely regarded as the most determined supporter of the EU's Eastern enlargement and as one of the most, if not the most, important player in enlargement politics (Grabbe and Hughes 1998: 57; Gower 1999: 8; Baun 2000: 41; Smith 2000: 133; Colegrove 2005: 131). Accordingly, the German discourse can be considered particularly important. This legitimates a focus on Germany, though it does not, of course, make for a representative account of the EU's enlargement discourse in general. To get a broader picture, the present study would need to be replicated for other members.

The empirical analysis is structured as follows. Altogether, five conventional metaphors will be discussed. For each, I will first spell out how it imagines the enlargement process; second, explore what image of Europe this metaphorization of enlargement conveys; third, discuss what kind of European identity the metaphor constructs; and fourth, reflect on how this conditions possible actions. In a final section, the results of my analysis will be summarized so as to 
allow for an answer to this article's principle question: is European identity post-modern?

\section{Enlargement as a family reunion}

One of the most powerful images of EU enlargement is that of a 'family reunion' (Kinkel, Foreign Secretary, 15 December, 1994: 399). ${ }^{22}$ In this picture, the applicant countries are 'our European brothers' (Kohl, Chancellor, 15 December, 1994: 420) and therefore they belong to the 'European family of nations' (Merz, CDU/CSU, 8 June, 2000: 10118). Obviously, Europe is imagined here as a family. If enlargement reunites the European family, this implies that the family members have been apart from each other, that the family has been split. Enlargement brings the family back together.

How does the family metaphor construct European identity? To answer this question means reconstructing the projection from the source to the target domain, to actually make sense of Europe in terms of a family. Families are characterized by the fact that membership is given by birth and ends only with death. Family members identify with each other due to them sharing the same origin. Families are natural collectivities. In consequence, I would argue that the metaphorization of Europe as a family constructs the European identity as being based on primordial sources. What about the mode of differentiation implied by the family metaphor? Families, as natural entities, have clear boundaries. One is either a member of the family or not - in the case of doubt, a blood test will decide. As a blood relationship defines whether one is inside or outside, it is impossible to cross the boundary. Those not born European cannot possibly become European later on. This discriminates between countries that are considered to be original, natural European countries and countries that are not. Obviously, there is nothing in-between; if a country is not originally part of Europe, it will remain its other permanently. Clearly, a European identity so understood follows the digital mode of differentiation. In total, the family metaphor constructs a European identity according to the German model, combining the primordial source and digital mode of differentiation.

However, the family metaphor can also be interpreted differently. Above, I have stressed that families are natural units, defined by a blood relationship. This, as we all know, is not entirely true. It is possible to become a family member even after birth, either by adoption or by marriage. If one emphasizes these possibilities, families are not so much natural but social entities. The source of identification here is not the shared origin, but the interaction within the social institution of family. If one applies this to our case, it means that the family metaphor constructs a European identity founded on a civic base. As to the mode of differentiation, however, this civic reading of the family metaphor 
leads to similar results as the primordial interpretation. Although the boundary is obviously more open than above - spouses marry, children are adopted it is still well guarded. That someone can cross over is a rare exception. Even if understood as civic entities, families are very exclusive. Also, their boundaries are clearcut. Although there are some means for a more gradual transition from the inside to the outside, most notably the social institution of engagement, from a legal perspective at least there is no ambiguity. There is always a precise moment when a new membership starts, for example, the moment the spouse says 'yes'. Hence, even the civic interpretation of a family allows us to easily distinguish between the self and other. Here too, differentiation follows the digital mode.

In sum, we are confronted with a somewhat confusing picture. Apparently, the family metaphor constructs a primordial and civic identity, although in both cases it relies on the digital mode of differentiation. However, I would hold that the primordial interpretation is more convincing as it has more empirical substance: that enlargement is metaphorized as a re-union hardly allows for an interpretation that we are dealing here with a marriage or adoption. It re-constitutes the original state, the primordial entity. Also, the applicants are not said to be the spouses, but the brothers. Overall, the family metaphor is used in a way that points more towards a primordial construction of European identity than towards a civic one.

What are the political implications of the family metaphor? Most importantly, it depoliticizes the enlargement process. If the CEECs are part of the family, it is not up for discussion whether they can join the EU. Their membership is, so to speak, a natural right that can be claimed by the applicants. This conclusion was drawn explicitly by former Chancellor Helmut Kohl:

[T] he Poles, the Czechs, the Slovaks, the Romanians, the Bulgarians and the Hungarians are our European brothers [...] and need to attain their European rights (Kohl, Chancellor, 15 December, 1994: 420).

This, of course, implies that the EU cannot reject the applicants, regardless of whether or not other criteria for membership are fulfilled (in fact, there can be no other criteria, according to this interpretation). At least if the applicants are the EU's brothers, not the EU's children, the family metaphor constructs a non-hierarchical relationship between them. The candidates and the EU meet on equal terms, the latter cannot dictate its terms upon the former. Lastly, the family metaphor also conditions a very restrictive approach to further enlargement. While those countries that are part of the family have a natural right to join, other countries cannot possibly be taken up. The EU can turn down membership bids by simple reference to the respective country not being part of the family, of the primordially defined Europe. Hence, the family 
metaphor not only obliges the EU to integrate a certain group of countries but also enables it to reject the membership requests of anyone else.

\section{Enlargement as a homecoming}

Especially in the early 1990s, it was very common among German politicians to describe EU enlargement as enabling the CEECs' 'homecoming to Europe' (Kohl, Chancellor, 30 January, 1991: 85). As one deputy declared: 'The Central and Eastern Europeans need a European perspective: They want home to Europe' (Haussmann, FDP, 6 November, 1991: 4378). Here, the source domain 'homecoming' is mapped onto the target domain 'EU enlargement'. This implies the metaphorization of the EU as 'home'. Further, the applicant countries are anthropomorphized as persons who for some time have gone away from home and now want to return. The EU/Europe is the applicants' home, their place of origin. This image is similar to that created by the family metaphor: the CEECs and the EU members originally belonged together, but they had been separated from each other for some time.

The homecoming metaphor also constructs a European identity. Like the family metaphor, it emotionalizes the EU. No longer is it just a political organization, but as a home (or family), it is something people have strong feelings about. If we understand identity as a sense of belonging, such emotionalization is an important part of creating identity. But where does this sense of belonging come from, is it natural or social? Like the family metaphor, the homecoming metaphor is above all constructing a primordial European identity. As with one's family, one cannot choose the place where one comes from, it is a given. I am not only born into a family but also into a cultural, historical and geographical context. I cannot do anything about my origin, my 'home' is very much a primordial fact. So, as the CEECs are originally part of this home, the so constructed primordial European identity includes them.

With the family metaphor, I have argued that, while it constructs a European identity mostly on primordial grounds, there is also some degree of civicness. With respect to the homecoming metaphor, one could make a similar point: while home is first of all a natural given, one may have more than just the one, original home. One can move away from the place one grew up in (one's natural home) and settle in a new place, which over time becomes one's new home. The latter home is acquired, hence it provides a civic rather than a primordial identity (although it will become the natural home for one's children). Therefore, one could argue that the homecoming metaphor does not necessarily construct a primordial European identity, yet it also allows for the idea of Europe being a home not only to those who were born there but also to those who have chosen to live there. 
However, like in the family metaphor case, I find the primordial interpretation more convincing. The metaphor use apparently rests on the idea that the home is an original home. The applicant countries had originally lived there, that is where they naturally belong. Now, after years of separation from their home, they are allowed to come back. We find the primordial interpretation of the homecoming metaphor confirmed by statements like the following, where the original belonging is emphasized by use of the term 'always':

Prague, Warsaw and Budapest, Sofia and Bucharest returned - in our consciousness, too - to where they always belonged: to the one, indivisible Europe (Kinkel, Foreign Secretary, 20 May, 1992: 7647).

What is the EU's/Europe's mode of differentiation according to the homecoming metaphor? This depends on whether one takes the home metaphor to base European identity on a primordial source, as I do, or whether one puts more emphasis on the civic source. In the former case, the mode of differentiation is a digital one. The home metaphor constructs a clear difference between those who are originally part of Europe and those who are not. Either I was born in Europe, then this is my home, or I was born elsewhere, then Europe cannot be my home. The border is clearcut and virtually impossible to cross. If, however, one argues that the homecoming metaphor constructs a civic European identity, one can see an analog mode of differentiation at work here: if one can acquire a home by moving to a place and living there for long enough, then the border becomes more open. It also becomes more difficult to distinguish between the self and other. The self and other may even live in the same place, but they moved there at different points in time, as a result of which one is more accustomed to the place than the other, more socialized into the home. They have acquired different degrees of civic identity. Apparently, the difference in this case is more gradual, differentiation works according to the analog mode.

However, as the civic interpretation of the homecoming metaphor is quite weak, the interpretation of their operating an analog mode of differentiation is not very strong either. In my view, the homecoming metaphor's identity-construction is not very far from the family metaphor. Just like the family metaphor, it primordializes the European identity, and by doing so, it differentiates the original Europe from the original Non-Europe in a digital way. It is only the original belonging together that matters, and this original state cannot possibly be acquired afterwards. The border between the self and other is clearly defined and insurmountable. Therefore, the homecoming metaphor also makes for a combination of the primordial source and digital mode, and thus shapes the European identity according to the German model of national identity. 
The homecoming metaphor not only shapes European identity but also political action. The result is similar to the family metaphor's policy implications. The EU members can hardly deny membership to countries with which they share a home, despite the fact that the applicants had to leave home for some time. They have always retained a natural right to return, and now they are exercising it. But just as this construction makes it impossible not to take up those applicant countries described as coming home, it enables the EU to turn down those other countries that cannot claim that Europe is their home.

\section{Enlargement as growing together}

Another metaphor often heard in the Bundestag is that of 'Europe growing together' (Rühe, CDU/CSU, 10 November, 1998: 70), of a 'coalescing Europe' (Wieczorek-Zeul, SPD, 22 June, 1995: 3549). Here, EU enlargement is an organic process and, as such, something natural. In this understanding, Europe is a living organism. Consider the following statement:

For more than 50 years the countries of Central and Eastern Europe were violently forced to deny their historically grown connections with Western Europe [...] It is in our interest to support the growing together of Europe (Francke, CDU/CSU, 28 February, 1997: 14532).

What follows for the construction of identity? Here, I would hold, we are dealing with an almost prototypical example of an identity-construction of the primordial plus digital type. European identity is based on a truly natural source: Europe is an organism and every European country makes up part of this organism. It follows that the metaphor constructs a digital difference between the self and other; a country is either part of that organism or not. Whereas the border between the self and other can in principle - although with great difficulties - be crossed in the case of the family and homecoming metaphors, it cannot be overcome in the case of the organic metaphor; it runs between natural Europeans and natural NonEuropeans.

One could, perhaps, mistake the metaphor for pointing to an analog mode of differentiation: growing together implies that there is a process going on, a development at the end of which two separate things are united. However, in nature growing together is not an arbitrary process. Not just any two things can grow together. The latest achievements of modern medicine notwithstanding, we can assume that a certain natural relationship is a precondition for two things to grow together. Hence, the coalescence mapped onto EU enlargement takes place between similars; it happens within the European organism, not 
between the organism and others. This logic of reconstituting an original identity is spelled out in the following statement:

What belongs together is now growing together again in the whole of Europe (Kinkel, Foreign Secretary, 26 March, 1998: 20431).

What are the political consequences of metaphorizing EU enlargement in organic terms? I can be brief here since the effect is similar to the family and homecoming metaphors: enlargement is a natural process that cannot and should not be impeded. Countries that are part of the European organism cannot be denied accession to the EU as their separation from the EU is an unnatural state (perhaps one can think of it as a broken leg). EU enlargement recovers the original, the natural state in Europe. Another consequence of this metaphor is that it enables a laissez-faire approach to enlargement. If enlargement happens anyway, so to say naturally, neither the EU nor the applicants have to put much political effort into it.

\section{Enlargement as a path}

The one metaphor that the enlargement-discourse apparently cannot do without is the path metaphor: ${ }^{23}$ the candidates are said to be 'on the way to the EU (Schröder, Chancellor, 16 December, 1999: 7213), accession is described as the candidates' 'rapprochement' (Stoiber, CDU/CSU, 11 March, 1993: 16297) or as a process where the candidates are being 'led' (Irmer, SPD, 17 October, 1991: 4082) to the EU. Speakers demand to help applicants 'to faster cover the distance' (Haussmann, FDP, 3 December, 1999: 7072), call for an 'overtaking lane for the faster' countries (Kinkel, Foreign Secretary, 26 November, 1997: 18701), or warn against uncoupling the Baltic states from the 'European train' (Kinkel, Foreign Secretary, 28 February, 1997: 14545). Implicitly, the path metaphor imagines the EU as the end point of this path, the final destination towards which the candidates are heading.

The identity-construction of the path metaphor is different from the metaphors discussed above, both with respect to the source and the mode of differentiation. While the other metaphors construct a primordial identity of Europe, no natural or cultural basis for identity can be seen here. The EU members, which are at the end point of the path, are united only by being there at the end of the path. If we see the path as describing the integration process itself, the end point marks a very high degree of political integration. European identity thus derives from political cooperation, from the institutions developed to enable cooperation. It is based on civic sources.

How does the EU differentiate itself from its others in this picture? The applicant countries are situated somewhere along the path, neither at its 
beginning nor at its end. Thus, they are constructed as different from the EU members, yet the difference is not as absolute as in the case of primordial identities: instead of the clearcut and difficult-to-cross border that keeps 'us' and 'them' apart in primordial identities, a path allows for gradual differences. It constructs a frontier zone rather than a clear border. The path metaphor constructs a European identity as a continuum between complete identity and complete difference with innumerable points in-between. Where exactly a candidate country is situated on this continuum depends on the degree of its familiarity with the rules and routines that are at the centre of the EU's civic identity. Clearly, this place is not fixed forever. It changes as the candidate takes over more and more of the 'acquis communautaire', something commonly described as 'rapprochement' to the EU.

We can summarize that the path metaphor constructs a European identity that rests upon civic sources and relates to its others according to the analog mode. Hence, it fits into the lower-right-hand field of the above table. While the other metaphors discussed so far imagine European identity very much like national identities, the path metaphor diverts from nationalist identityconstructions. The metaphorization of EU enlargement as a path makes for a post-modern/post-national identity-construction.

What is the path metaphor's impact on political action? The most important consequence is that enlargement is now a political process, which has nothing to do with original belonging. In principle, the EU is open to anyone willing to cooperate ever more closely with it. Whereas the metaphors discussed above made it impossible for the EU to deny membership to the applicants as they were constructed to be a natural part of the self, the path metaphor reconstitutes the EU's political control over the accession process. It allows the EU to set the conditions the applicants have to fulfil if they want to continue on the path towards the EU.

\section{Enlargement as entry into a house}

One of the key metaphors in the European integration discourse generally is the house metaphor (Chilton and Ilyin 1993; Schäffner 1996; Musolff 2004: 122-40). It comes in many variations but all basically imagine Europe/the EU as a house. The 'deepening' of the EU, for example, is often described as 'building the European house', and the pillar metaphor has officially been applied to the organizational structure of the EU. In the German enlargementdiscourse, the house metaphor is also prominent. In this picture, enlargement is the candidates' entry, their 'coming into the European house' (Kohl, Chancellor, 8 November, 1995: 5764). The EU members are already inside the house. The applicants, by contrast, are found to be 'queuing' (Kinkel, Foreign Secretary, 8 October, 1992: 9316) in front of the house, 'knocking on 
its door' (Meckel, SPD, 18 March, 1999: 2189), and shouting 'let us in' (Kinkel, Foreign Secretary, 26 March, 1998: 20431). The Bundestag debated about 'opening the door to the European house' (Stoiber, CDU/CSU, 11 March, 1993: 16298), and speakers were warned against telling the applicants 'that, unfortunately, there is no vacant room for you in the European house' (Kinkel, Foreign Secretary, 2 April, 1998: 20807).

The house metaphor constructs a civic European identity. The member states live in the same house. They meet each other in the hallway, they follow certain rules and over time develop common social routines. These practices can lead to the emergence of a civic identity. The applicant countries, however, cannot participate in these common practices because they are outside the house. But their being outside is not due to cultural or ethnic reasons - it is the result of politics. Those inside the house have decided that they do not want to open the door. One day, they may decide to open it, then the outsiders would become residents of the house and thus partake in the civic identity that has developed there. But 'time, patience, and a certain cautiousness to avoid anything extraordinary are indispensable for this endeavour' (Eisenstadt and Giesen 1995: 81), for becoming familiar with the rules of the inside. That is why the candidates are not simply let in but have to wait in front of the house. There, they may be able to learn something about the rules and norms of the residents simply by watching through the window. This is part of the socialization process that makes it possible to eventually acquire a civic identity.

According to the house metaphor, Europe/the EU organizes its outsideborder in a digital way. There is a clear difference between 'us' and 'them' 'we' are inside, 'they' are outside the house. The house's external walls mark the boundary that keeps the self and other apart, leaving no ambivalence. One can only be either inside or outside but not - as in the case of path metaphors - halfway in. Hybridity or multiple identities (being in two houses at the same time?) cannot be imagined with the house metaphor. However, the border between the inside and outside is not impermeable. Houses have doors and it is precisely the purpose of doors to enable entry and exit. By stepping through the door, candidates enter the house and at this moment become part of the self. Accordingly, the border that separates the inside and outside is more open than in the case of the primordial metaphors. While there is a clearcut difference between the self and other, it is not an absolute difference.

In sum then, the European identity constructed by the house metaphor is one that builds on civic sources and has a digital mode of differentiation. This qualifies it for a place in the lower-left field of our table, the French type of identity. It demonstrates that a civic identity does not necessarily have to go hand in hand with an analog mode of differentiation. We are able to imagine a civic identity, which is accompanied by clearcut borders, neatly separating the self from the other. 
The implications of the house metaphor for enlargement politics are similar to the path metaphor. The crucial point is that it makes enlargement a matter of politics. It is not a primordial condition that decides about membership, but whether or not the EU takes an applicant to be ready for membership. This equips the EU with more agency as compared to the primordial metaphors. As there is no natural obligation to grant membership to the CEECs, the EU is free to reject any of them. The clearcut boundaries of a Europe/EU so constructed also allow the rejecting of applicants with reference to the EU's own capacity. The EU can now argue that there is no vacancy in the house and that, therefore, the accession of new members is impossible. This is different from the path metaphor where the difference between EU members and nonmembers is gradual. Where the path metaphor enables the EU to offer applicants a status between membership and non-membership, a sort of second-class membership, this possibility does not exist here. There is only full membership or nothing at all.

\section{Summary: is European identity post-modern?}

In this chapter, I have tried to reconstruct how European identity is constituted in the enlargement-discourse. The family metaphor, the homecoming metaphor and the metaphor of growing together primordialize European identity and set up a digital mode of differentiation. In this way, European identity looks very similar to German identity. Obviously, there is nothing post-modern about it, it is very much in line with modern, nationalist ways of constructing identity. The same holds true for the house metaphor that constructs the European identity as a combination of a civic source and digital mode of differentiation - corresponding to the French national identity. However, this type of identity is arguably less nationalistic and more benign than the primordialdigital combination as the difference between the self and other is not natural. In principle, the other can become part of the self. The border is clearcut but not insurmountable. However, only one of the metaphors discussed actually constructs the European identity in a post-modern/post-national way: the path metaphor not only bases European identity on civic sources but also breaks

Table 2 Metaphors in the two-dimensional model of identity

\begin{tabular}{llll}
\hline & & Mode of differentiation & \\
\cline { 3 - 4 } & & Digital & Analog \\
\hline Source of differentiation & $\begin{array}{l}\text { Primordial } \\
\text { Civic }\end{array}$ & Family, growing together, homecoming & \\
& House & Path \\
\hline
\end{tabular}


with the habit of imagining identity exclusively. Here, the other is no longer absolutely different, but only different in degree. The self and other are not separated by a clearcut border, instead they are connected by a transition zone, which can make it difficult to say where the self ends and the other begins.

As a result, the five metaphors can now be situated in our $2 \times 2$ table (Table 2).

\section{Conclusion}

The European identity is in the making. This article has demonstrated how this works on the (discursive) ground: it has shown that the way we talk and the metaphors we use shape the European identity. Metaphors construct reality by projecting the meaning of a familiar domain, mostly from our everyday world, onto an unfamiliar, abstract domain. The European identity is certainly such an unfamiliar and abstract domain and, indeed, metaphors are used to understand and construct it. In the German discourse on the EU's Eastern enlargement during the 1990s, Europe/the EU was described as a family, an organism, a home, the end point of a path, and a house. Conventional IR studies would ignore these instances of metaphorical speaking, dismissing them as mere rhetoric with no political impact. I have argued that these metaphors do matter: they constitute the EU enlargement and European identity. They condition how we can think of Europe, what we can meaningfully say about Europe and also what we can do about it. If, for instance, Europe is described as a family and an applicant country as not being a member of that family, this is a metaphorical construction that constitutes the applicant as Europe's other. Further, it enables that country's exclusion from the enlargement process.

But what kind of European identity is in the metaphorical making? Is it a post-modern identity as claimed by some? While an analysis of the EU's 'layered' political structure indicates a post-modern polity, I have argued that taking the imagined character of communities seriously prevents looking only at the EU's political structure to find out about its identity. One also has to take account of the way Europe is imagined. The metaphors by which we imagine Europe do not tell us a very post-modern story, but one that reminds us of modern, national identities. With the sole exception of the path metaphor, the metaphors of EU enlargement construct a European identity that remains firmly linked to the modern, digital mode of differentiation. Further, several of the metaphors even primordialize the European identity. This indicates that the 'supranationalist temptation whereby the European Union would try to boost its legitimacy and its ostensible security of self by copying the experience of European nation-states and try to forge a full-fledged ethnopolitical rhetoric' (Neumann 1998: 413) is very present. In the Bundestag, 
Europe is imagined and thus constructed much like Germany itself - as a Kulturnation on a larger scale. The German discourse imagines a European identity in the (supra-)nationalist way. This is not surprizing because metaphors are conservative. They project our old patterns of imagining and constructing political organizations into the future. As such, they can be a serious obstacle to overcoming the modern, nationalist age. We are quite unable to imagine our future differently from our past. Therefore, imagining a world where 'there's no countries' is much harder to do than John Lennon expected.

\section{Acknowledgements}

I thank my colleague Alexander Spencer and the anonymous referees of the Journal of International Relations and Development for their helpful comments.

\section{Notes}

1 Examples include Ruggie (1993), Wæver (1998), Axford and Huggins (1999), Cooper (2000), Cederman (2001), Schimmelfennig (2001), van Ham (2001), Manners and Whitman (2003), and Scott (2005).

2 See, for example, Neumann (1998, 1999), Diez (1999, 2004), and Rumelili (2004).

3 In the following, I will use the terms EU and Europe largely interchangeably. I thereby adhere to a common language practice in both the political and academic discourse on European integration whereby Europe has become something of a synonym for the EU. I will thus read the discourse on EU enlargement as constructing European identity, although, strictly speaking, it constructs an EU identity.

4 The volume on The Return of Culture and Identity in IR Theory, edited by Lapid and Kratochwil (1996), has been particularly influential in this respect.

5 Here, Anderson's (1983) notion of 'imagined communities' has been crucial. Exceptions, of course, remain. Huntington's 'Clash of Civilizations' (1993) is arguably the most famous IR example of a pronounced essentialist understanding of identity.

6 David Campbell's study of the United States foreign policy was groundbreaking in this respect (Campbell 1998: 9); also Neumann (1996).

7 Although the exact labelling varies, examples for the primordial/civic distinction include Wæver and Kelstrup (1993), Wæver (1998), Neumann (1998, 1999), Schimmelfennig (2001), Bruter (2003, 2005), and Manners and Whitman (2003). Eisenstadt and Giesen (1995) introduce culture as an additional source (they talk of 'code'), which we subsume to the primordial source.

8 That a constructivist understanding of identity has acquired an almost common sense status in the literature becomes apparent from the fact that even in a recent positivist, quantitative study on The Changing Face of European Identity (Robyn 2005a), the authors explicitly avow themselves to a constructivist understanding of identity (Robyn 2005b: 17).

9 To name but a few examples: Robins and Aksoy (1995), Delanty (1996), Neumann $(1998,1999)$, and Rumelili (2004).

10 For the former view, see Neumann (1998) and Rumelili (2004); for the latter, see Wæver (1998), Schimmelfennig (2001), and Manners and Whitman (2003).

11 For example, Schimmelfennig (2001) and Manners and Whitman (2003) seem to conflate primordial and national, as well as civic and post-national. 
12 I thank the editors for having alerted me to this point.

13 For an overview of the phenomenon of 'differentiated integration', see Stubb (1996).

14 The $2 \times 2$ table-logic is, of course, a crude simplification of each dimension. Rather than being split into two mutually exclusive categories, empirical reality probably resembles more of a continuum between the two categories in each dimension. However, it is the strength of dichotomizations to reduce empirical complexity and to force us to focus on the most crucial differences.

15 That civic sources can be combined with digital as well as with analog modes of differentiation shows that the two dimensions of my identity-model do indeed describe two separate aspects of identity instead of being just two ways of saying the same thing.

16 For example, Chilton and Ilyin (1993), Chilton and Lakoff (1995), Chilton (1996), Milliken (1996), Mutimer (1997), Fierke (1998), Agathangelou and Ling (2004), Beer and De Landtsheer (2004), Drulak (2004), and Luoma-aho (2004).

17 For example, Bachem and Battke (1991), Thornborrow (1993), Schäffner (1995, 1996), Straehle et al. (1999), and Musolff (2000, 2004).

18 A similar approach is that of 'artificial foolishness' (Hitzler 1993: 230).

19 This technique, of course, recalls the post-structuralist 'method' of deconstruction, that is, denaturalizing and making strange taken-for-granted meanings (cf. Der Derian 1989: 4; Gregory 1989: xiv).

20 For overviews of the enlargement process, see Grabbe and Hughes (1998), Mayhew (1998), Gower (1999), Baun (2000), and Smith (2000).

21 For a detailed account of this analysis, see Hülsse (2003). There, I also examine whether there was a difference in metaphor use depending on whether the CEECs' or Turkey's accession was discussed.

22 All quotations are identified by reference to the speaker's name and function or party membership, the date of the session and the page number in the respective official minute. The minutes can be accessed at http://www.bundestag.de/bic/plenarprotokolle/index.html (3 August, 2006). All translations are mine. Note that I have tried to translate as literally as possible, obviously at the expense of elegance.

23 This impression is confirmed by a quantitative analysis of European metaphors by Musolff, who finds path metaphors to be the largest group of metaphors in his corpus (Musolff 2000: 9).

\section{References}

Agathangelou, Anna M. and L. H. M. Ling (2004) 'The House of IR: From Family Power Politics to the Poises of Worldism', International Studies Review 6(4): 24-49.

Agnew, John (2001) 'How Many Europes? The European Union, Eastward Enlargement and Uneven Development', European Urban and Regional Studies 8(1): 29-83.

Anderson, Benedict (1983) Imagined Communities: Reflections on the Origin and Spread of Nationalism, London: Verso.

Anderson, Malcolm (1998) 'European Frontiers at the End of the Twentieth Century: An Introduction', in Malcolm Anderson and Eberhardt Bort, eds, The Frontiers of Europe, 1-10, London: Palgrave Macmillan.

Axford, Barrie and Richard Huggins (1999) 'Towards a Post-National Polity: The Emergence of the Network Society in Europe', in Dennis Smith and Sue Wright, eds, Whose Europe? The Turn Towards Democracy, 173-206, Oxford: Blackwell.

Bachem, Rolf and Kathleen Battke (1991) 'Strukturen und Funktionen der Metapher "unser gemeinsames Haus Europa" im aktuellen politischen Diskurs', in Frank Liedtke, Martin 
Wengeler and Karin Böke, eds, Begriffe besetzen: Strategien des Sprachgebrauchs in der Politik, 295-307, Opladen: Westdeutscher Verlag.

Baun, Michael J. (2000) A Wider Europe: The Process of European Union Enlargement, Lanham, MD: Rowman \& Littlefield.

Beer, Francis A. and Christ'l De Landtsheer, eds (2004) Metaphorical World Politics, East Lansing, MI: Michigan State University Press.

Berger, Peter L. and Thomas Luckmann (1966) The Social Construction of Reality: A Treatise in the Sociology of Knowledge, New York: Doubleday.

Bhaba, Homi K. (1996) 'Culture's In-Between', in Stuart Hall, ed., Questions of Cultural Identity, 53-60, London: Sage.

Böke, Karin (1997) 'Die "Invasion" aus den "Armenhäusern Europas": Metaphern im Einwanderungsdiskurs', in Mathias Jung, Martin Wengeler and Karin Böke, eds, Die Sprache der Migrationsdiskurse: Das Reden über die 'Ausländer' in Medien, Politik und Alltag, 164-93, Opladen: Westdeutscher Verlag.

Bruter, Michael (2003) 'Winning Hearts and Minds for Europe: The Impact of News and Symbols on Civic and Cultural European Identity', Comparative Political Studies 36(10): 1148-79.

Bruter, Michael (2005) Citizens of Europe? The Emergence of a Mass European Identity, Houndmills: Palgrave Macmillan.

Buzan, Barry and Thomas Diez (1999) 'The European Union and Turkey', Survival 41(1): $41-57$.

Calhoun, Craig (2001) 'The Virtues of Inconsistency: Identity and Plurality in the Conceptualization of Europe', in Lars-Eric Cederman, ed., Constructing Europe's Identity: The External Dimension, 35-56, Boulder, CO: Lynne Rienner.

Campbell, David (1998) Writing Security: United States Foreign Policy and the Politics of Identity, Minneapolis, MN: University of Minnesota Press.

Cederman, Lars-Erik (2001) 'Exclusion Versus Dilution: Real or Imagined Trade-Off?', in Lars-Erik Cederman, ed., Constructing Europe's Identity: The External Dimension, 233-56, Boulder, CO: Lynne Rienner.

Charteris-Black, Jonathan (2004) Corpus Approaches to Critical Metaphor Analysis, Houndmills: Palgrave Macmillan.

Chilton, Paul (1996) Security Metaphors: Cold War Discourse from Containment to Common House, New York: Peter Lang.

Chilton, Paul and George Lakoff (1995) 'Foreign Policy by Metaphor', in Christina Schäffner and Anita Wenden, eds, Language and Peace, 37-59, Aldershot: Dartmouth.

Chilton, Paul and Mikhail V. Ilyin (1993) 'Metaphor in Political Discourse: The Case of the "Common European House", Discourse \& Society 4(1): 7-31.

Christiansen, Thomas, Fabio Petito and Ben Tonra (2000) 'Fuzzy Politics around Fuzzy Borders: The European Union's "Near Abroad", Cooperation and Conflict 35(4): 389-415.

Colegrove, De Forest W. (2005) 'Steadfastly European? German (Supra)national Identity in a Rapidly Changing Europe', in Richard Robyn, ed., The Changing Face of European Identity, 115-39, London: Routledge.

Cooper, Robert (2000) The Postmodern State and the World Order, London: Demos.

Delanty, Gerard (1996) 'The Frontier and Identities of Exclusion in European History', History of European Ideas 22(2): 93-103.

Der Derian, James (1989) 'The Boundaries of Knowledge and Power in International Relations', in James Der Derian and Michael J. Shapiro, eds, International/Intertextual Relations: Postmodern Readings in World Politics, 3-10, Lexington, MA: Lexington Books.

Derrida, Jacques (1992) Das andere Kap: Die vertagte Demokratie. Zwei Essays zu Europa, Frankfurt am Main: Suhrkamp. 
Diez, Thomas (1999) 'Constructing Threat, Constructing Political Order: On the Legitimisation of an Economic Community in Western Europe', Journal of International Relations and Development 2(1): 29-49.

Diez, Thomas (2004) 'Europe's Others and the Return of Geopolitics', Cambridge Review of International Affairs 17(2): 319-35.

Doty, Roxanne Lynn (1993) 'Foreign Policy as Social Construction: A Post-Positivist Analysis of US Insurgency Policy in the Philippines', International Studies Quarterly 37(3): 297-320.

Drulak, Petr (2004) 'Metaphors Europe Lives by: Language and Institutional Change of the European Union', Florence: European University Institute, EUI Working Paper SPS, No. 2004/15.

Eco, Umberto (1995) Die Grenzen der Interpretation, München: Hanser.

Eisenstadt, Shmuel N. and Bernhard Giesen (1995) 'The Construction of Collective Identity', Archive européenne de sociologie 36(1): 75-102.

Fairclough, Norman (1992) Discourse and Social Change, Cambridge: Polity Press.

Fierke, Karin M. (1998) Changing Games, Changing Strategies: Critical Investigations in Security, Manchester: Manchester University Press.

Fierke, Karin M. and Antje Wiener (1999) 'Constructing Institutional Interests: EU and NATO Enlargement', Journal of European Public Policy 6(5): 721-42.

Gower, Jackie (1999) 'EU Policy to Central and Eastern Europe', in Karen Henderson, ed., Back to Europe: Central and Eastern Europe and the European Union, 3-21, London: UCL Press.

Grabbe, Heather and Kirsty Hughes (1998) Enlarging the EU Eastward, London: Royal Institute of International Affairs, Chatham House Paper.

Gregory, Donna U. (1989) 'Foreword', in James Der Derian and Michael J. Shapiro, eds, International/Intertextual Relations: Postmodern Readings of World Politics, xiii-xxi, Lexington: Lexington Books.

Hedetoft, Ulf (1997) 'The Cultural Semiotics of "European Identity": Between National Sentiment and the Transnational Imperative', in Alice Landau and Richard Whitman, eds, Rethinking the European Union: Institutions, Interests and Identities, 147-70, Basingstoke: Macmillan.

Hitzler, Ronald (1993) 'Verstehen: Alltagspraxis und wissenschaftliches Programm', in Thomas Jung and Stefan Müller-Dohm, eds, Wirklichkeit' im Deutungsprozeß: Verstehen und Methoden in den Kultur- und Sozialwissenschaften, 223-40, Frankfurt am Main: Suhrkamp.

Hülsse, Rainer (2003) Metaphern der EU-Erweiterung als Konstruktionen europäischer Identität, Baden-Baden: Nomos.

Huntington, Samuel (1993) 'The Clash of Civilizations?', Foreign Affairs 72(3): 22-49.

Kuus, Merje (2005) 'Multiple Europes: Boundaries and Margins in European Union Enlargement', Geopolitics 10(3): 567-70.

Lakoff, George and Mark Johnson (1980) Metaphors We Live By, Chicago, IL: The University of Chicago Press.

Lapid, Yosef and Friedrich Kratochwil, eds (1996) The Return of Culture and Identity in IR Theory, London: Lynne Rienner.

Luoma-aho, Mika (2004) "“Arm" versus "Pillar": The Politics of Metaphors of the Western European Union at the 1990-91 Intergovernmental Conference on Political Union', Journal of European Public Policy 11(1): 106-27.

Manners, Ian and Richard G. Whitman (2003) 'The "Difference Engine": Constructing and Representing the International Identity of the European Union', Journal of European Public Policy 10(3): 380-404.

Mayhew, Alan (1998) Recreating Europe: The European Union's Policy towards Central and Eastern Europe, Cambridge: Cambridge University Press.

Milliken, Jennifer (1996) 'Metaphors of Prestige and Reputation in American Foreign Policy and American Realism', in Francis Beer and Robert Hariman, eds, Post-realism: The Rhetorical Turn in International Relations, 217-38, East Lansing, MI: Michigan State University Press. 
Milliken, Jennifer (1999) 'The Study of Discourse in International Relations: A Critique of Research and Methods', European Journal of International Relations 5(2): 225-54.

Moravcsik, Andrew (2001) 'Despotism in Brussels? Misreading the European Union', Foreign Affairs 80(3): 114-22.

Murphy, Alexander B. (2005) 'The Changing Geography of Europeaness', Geopolitics 10(3): 586-91.

Musolff, Andreas (2000) Mirror Images of Europe: Metaphors in the Public Debate about Europe in Britain and Germany, München: Iudicium.

Musolff, Andreas (2004) Metaphor and Political Discourse: Analogical Reasoning in Debates about Europe, Houndmills: Palgrave Macmillan.

Mutimer, David (1997) 'Reimagining Security: The Metaphors of Proliferation', in Keith Krause and Michael C. Willliams, eds, Critical Security Studies, 187-221, Minneapolis, MN: University of Minnesota Press.

Neumann, Iver B. (1996) 'Self and Other in International Relations', European Journal of International Relations 2(2): 139-74.

Neumann, Iver B. (1998) 'European Identity, EU Expansion, and the Integration/Exclusion Nexus', Alternatives 23(3): 397-416.

Neumann, Iver B. (1999) Uses of the Other: 'The East' in European Identity Formation, Minneapolis, MN: University of Minnesota Press.

Robins, Kevin and Asu Aksoy (1995) 'Culture and Marginality in the New Europe', in Costis Hadjimichalis and David Sadler, eds, Europe at the Margins: New Mosaics of Inequality, 87-104, Chichester: Wiley.

Robyn, Richard, ed. (2005a) The Changing Face of European Identity, London: Routledge.

Robyn, Richard (2005b) 'Methodology', in Richard Robyn, ed., The Changing Face of European Identity, 17-36, London: Routledge.

Ruggie, John Gerard (1993) 'Territoriality and Beyond: Problematizing Modernity in International Relations', International Organization 47(1): 139-74.

Rumelili, Bahar (2004) 'Constructing Identity and Difference: Understanding the EU's Mode of Differentiation', Review of International Studies 30(1): 27-47.

Schäffner, Christina (1995) "“The Balance” Metaphor in Relation to Peace', in Christina Schäffner and Anita L. Wenden, eds, Language and Peace, 75-92, Aldershot: Dartmouth.

Schäffner, Christina (1996) 'Building a European House? Or at Two Speeds into a Dead End? Metaphors in the Debate on the United Europe', in Andreas Musolff, Christina Schaffner and Michael Towson, eds, Conceiving of Europe: Diversity in Unity, 31-59, Aldershot: Dartmouth.

Schimmelfennig, Frank (2001) 'Liberal Identity and Postnationalist Inclusion: The Eastern Enlargement of the European Union', in Lars-Erik Cederman, ed., Constructing Europe's Identity: The External Dimension, 165-86, Boulder, CO: Lynne Rienner.

Scott, James Wesley (2005) 'The EU and "Wider Europe": Toward an Alternative Geopolitics of Regional Cooperation?', Geopolitics 10(3): 429-54.

Smith, Martin A. (2000) Building a Bigger Europe: EU and NATO Enlargement in Comparative Perspective, Aldershot: Ashgate.

Straehle, Carolyn, Gilbert Weiss, Ruth Wodak, Peter Muntigl and Maria Sedlak (1999) 'Struggle as Metaphor in European Union Discourses on Unemployment', Discourse \& Society 10(1): 67-99.

Stubb, Alexander C.-G. (1996) 'A Categorization of Differentiated Integration', Journal of Common Market Studies 34(2): 283-95.

Thornborrow, Joanna (1993) 'Metaphors of Security: A Comparison of Representation in Defence Discourse in Post-Cold War France and Britain', Discourse \& Society 4(1): 99-119.

Tonkiss, Fran (1998) 'Analysing Discourse', in Clive Seale, ed., Researching Society and Culture, 245-60, London: Sage.

Torfing, Jacob (1999) New Theories of Discourse: Laclau, Mouffe, and Žižek, Oxford: Blackwell. 
Torfing, Jacob (2005) 'Discourse Theory: Achievements, Arguments, and Challenges', in David Howarth and Jacob Torfing, eds, Discourse Theory in European Politics: Identity, Policy and Governance, 1-32, Houndmills: Palgrave Macmillan.

van Ham, Peter (2001) European Integration and the Postmodern Condition: Governance, Democracy, Identity, London: Routledge.

Wæver, Ole (1996) 'European Security Identities', Journal of Common Market Studies 34(1): 103-32.

Wæver, Ole (1998) 'Explaining Europe by Decoding Discourses', in Anders Wivel, ed., Explaining European Integration, 100-46, Copenhagen: Copenhagen Political Studies Press.

Wæver, Ole (2002) 'Identity, Communities and Foreign policy: Discourse Analysis as Foreign Policy Theory', in Lene Hansen and Ole Wæver, eds, European Integration and National Identity: The Challenge of the Nordic States, 20-49, London: Routledge.

Wæver, Ole (2004) 'Discursive Approaches', in Antje Wiener and Thomas Diez, eds, European Integration Theory, 197-215, Oxford: Oxford University Press.

Wæver, Ole (2005) 'European Integration and Security: Analysing French and German Discourses on State, Nation, and Europe', in David Howarth and Jacob Torfing, eds, Discourse Theory in European Politics: Identity, Policy and Governance, 33-67, Houndmills: Palgrave Macmillan.

Wæver, Ole and Morten Kelstrup (1993) 'Europe and its Nations: Political and Cultural Identities', in Ole Wæver, Barry Buzan, Morten Kelstrup and Pierre Lemaitre, eds, Identity, Migration and the New Security Agenda in Europe, 61-92, London: Pinter.

Walters, William (2004) 'The Frontiers of the European Union: A Geostrategic Perspective', Geopolitics 9(3): 676-98.

\author{
About the Author \\ Rainer Hülsse is Assistant Professor at the University of Munich, Germany. \\ $\mathrm{He}$ is the author of 'Cool Turkey: Solving the Image Problem to Secure \\ EU-Membership', Mediterranean Politics 11(3), 2006.
}

